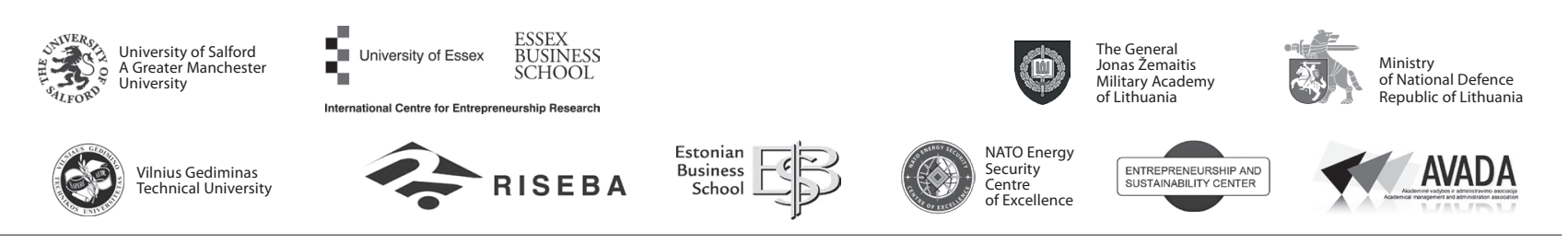

\author{
JOURNAL OF SECURITY AND SUSTAINABILITY ISSUES \\ ISSN 2029-7017 print/ISSN 2029-7025 online \\ 2017 December Volume 7 Number 2 \\ https://doi.org/10.9770/jssi.2017.7.2(13)
}

\title{
ORGANIZATIONAL AMBIDEXTERITY AS A PRELUDE TO CORPORATE SUSTAINABILITY
}

\author{
Sulphey, M. M. ${ }^{1}$; Nasser Saad Alkahtani ${ }^{2}$ \\ ${ }^{1,2}$ College of Business Administration, Prince Sattam Bin Abdulaziz University, Al-Kharj, Saudi Arabia \\ E-mails:1's.manakkattil@psau.edu.sa; ${ }^{2 n s . a l k a h t a n i @ p s a u . e d u . s a ~}$
}

Received 20 January 2017; accepted 22 September 2017

\begin{abstract}
Corporate Sustainability (CS) and Organisational Ambidexterity (OA) are two aspects that are capable of facilitating innovation in business. Though the concepts have been elaborately discussed separately, attempts are yet to be made to find out the association between them and blending of the two. Both CS and OA gathered the attention of social scientists and management experts only recently. However, within a short span of a few decades there has been sufficient accumulation of literature in these challenging areas. While CS involves a host of actions by which organizations strive for financial success, even as they accept the responsibility for their actions and its impacts on a diverse group of stakeholders; OA is the ability of an organisation to simultaneously explore and exploit, enabling it to succeed at adaption over time rather than pursing limited activities. The present paper attempts to find out the similarities and associations between CS and OA. It is expected, that the present work will add to the existing body of literature about the two concepts, and provide inputs for further research in this new and exciting area.
\end{abstract}

Key words: ambidexterity, organizational ambidexterity, contextual ambidexterity, exploration, exploitation, corporate sustainability

Reference to this paper should be made as follows: Sulphey, M. M.; Alkahtani, N.S. 2017. Organizational ambidexterity as a prelude to corporate sustainability, Journal of Security and Sustainability Issues 7(2): 335-347. https://doi.org/10.9770/jssi.2017.7.2(13)

JEL codes: L2

\section{Introduction and review of literature}

Organisations are now striving hard to become lean and agile to make them fit to take on the highly dynamic, competitive, turbulent and hedonistic market. They are now on the constant look out for strategies and innovative ideas towards this direction. Becoming sustainable is one such strategy that will ensure agility and long term success. Corporate sustainability (CS) has to be considered as a journey and not an end in itself, and it has been widely researched (Ahmed, McGough \& Mateo-Garcia, 2017; García-Fuentes \& De Torre 2017; Laužikas, Miliūtè, Tranavičius \& Kičiatovas, 2016; Rosha \& Lace, 2015; Sulphey, 2017; Sulphey \& Alkahtani, 2017; Tvaronavičiene, 2016).Becoming an ambidextrous organisation is another strategy that will facilitate continuous improvement and success. The present work intends to discuss the need for ambidexterity and corporate sustainability for organisations to achieve their declared goals. The first section, based on the available literature, discusses the concept of organisational ambidexterity (how an organization balances between the need of exploiting the existing capabilities, and simultaneously searching for new ones), and its offshoot "contextual ambidexterity". The second section discusses about corporate sustainability, which is now a buzzword in academic and industry circles. The article ends with the need for the harmonious blending of the two concepts would ensure that sustainability is embedded in the day-to-day life of the organization, enabling it to attain their long term goals. 


\section{Organisational Ambidexterity (OA)}

In ordinary parlance ambidexterity is "the ability to be skilful and agile at using both hands". Derived from this definition, OA has been an aspect of scholarly discussions for nearly four decades. Since the term ambidexterity is a complex phenomenon, and it signifies different meanings in different functional domains (O'Reilly and Tushman, 2013; Voss and Voss, 2013) and situations, it has been defined, modified and redefined over a period of time. A review of literature shows that references about OA are found as early as in 1976, wherein Duncan (1976) discussed about the concept and stated that the mechanism for managing ambidexterity include "sequential ambidexterity". Thereafter, Abernathy (1978) referred OA as "a firm's ability to be simultaneously efficient and innovative". However, research about OA received a renewed impetus with the publishing of the "seminal work" work of March (1991). In the last few decades, following the work of March (1991), substantial literature have accumulated about OA. However, there seems to be a lack of convergence about the concept. This could be due to the lack of a unified theoretical framework about the concept (Huber, 1991; Yan, Yu \& Dong, 2016).

The path breaking work of March (1991) succeeded in identifying "exploration" and "exploitation" as two different activities that lead to OA (Chang, Hughes \& Hotho, 2011; Raisch and Birkinshaw, 2008). While exploration, according to March (1991) is exploring novel ideas and opportunities that could foster innovation; exploitation is re-using of the existing resources and knowledge that could result in efficiency. There should be dexterity with respect to exploration and exploitation, as according to Yan, et al, (2016), concentration on either of it would result in disaster. Ever since March (1991) identified the concepts of exploration and exploitation, a number of social scientists and management experts have enriched the literature with their splendid works. The two concepts have been extensively usedin the context of organizational learning (Lavie, Stettner \& Tushman, 2010; Raisch \& Birkinshaw, 2008; Raisch, Birkinshaw, Probst \& Tushman, 2009; Yan, et al, 2016; Strielkowski, 2016). Both these concepts are considered as two fundamentally different activities that require and demand differing resources and attention of mangers (Chang et al., 2011).

As stated earlier, due to the evolving nature of literature about the concept and the absence of a unified theoretical framework, OA has been defined using a host of perspectives. Some such perspectives include organizational learning (March, 1991; Wang \& Rafiq, 2009; Yan, et al, 2016), organizational behavior and change management (Tushman \& O'Reilly, 1996), innovation management (He \& Wong, 2004; Jansen, Van den Bosch \& Volberda, 2005, 2006; Andriopoulos \& Lewis, 2009), leadership (Jansen et al.; 2008), and a few others (Jurksiene \& Pundziene, 2016; Turner, Swart \& Maylor, 2013). The importance of OA lies in the fact that is has to "be viewed as a strategic objective, representing the desired "ends" to be achieved via the appropriate "means" or organizational learning processes" (Yan, et al, 2016). In this context it would be ideal to consider a few definitions of OA.

\section{Defining the concept of $O A$}

The absence of a unified theoretical framework, as mentioned elsewhere in this work, has made OA to be defined using a host of perspectives and many variants or approaches (Parikh, 2016; Yan, et al, 2016); some of which are contradictory to each other. According to Tushman and O'Reilly (1996) ambidexterity is the ability of organizations to "exploit and explore simultaneously so as to contribute significantly to firm performance". The same authors later redefined the definition as the "ability to simultaneously explore and exploit, enabling a firm to succeed at adaption over time rather than pursing limited activities" (O'Reilly \& Tushman, 2007). Vera \& Crossan (2004) defined OA as "how an enterprise balances the need to exploit existing capabilities and search for new ones". For Rothaermel \& Deeds (2004) OA is:

"a dynamic capability by which organizations mobilize, coordinate, and integrate dispersed contradictory efforts, and allocate, combine and recombine resources and assets across differentiated exploratory and exploitive units".

It is also considered as the "organization's ability to simultaneously explore and exploit their internal and external resources to meet today's business needs as well as being adaptive to market changes" (O'Reilly and Tush- 
man, 2013; Raisch and Birkinshaw, 2008). Kathuria \& Konsynski (2012) conceptualized OA as a "higher-order construct" that is composed of explorative and exploitative capabilities.

Parikh (2016) defined it as "ability of organizations to simultaneously pursue contradictory goals". According to Armour (2015) OA is "the ability to focus on and balance the differing strategies of alignment and adaptability with equal success rates". Here the terms "alignment" and "adaptability" have a slightly different meaning from the colloquial ones. Alignment in this context is considered as the maintaining of a certain amount of consistency in all the activities wherein the organization has gained the required competence, and at the same time allowing a certain amount of incremental innovation. It is the coherence towards a common goal, wherein all the activities within the business unit is working in tandem and harmony. As against this, adaptability is the capacity of an organization to quickly realign and reconfigure the activities in the unit so as to meet the dynamic demands and at the same time involve in radical innovation (Gibson \& Birkinshaw, 2004). Alignment can be achieved through exploitation, and adaptability through exploration. It is possible to develop OA through encouraging individuals to make their own judgments as to how best they can divide their time between various conflicting demands for the sake of alignment and adaptability (March, 1991). However, according to Yan, et al, (2016), OA evolves over a period of time, as organizations have the necessity to continuously adapt to the highly volatile, uncertain and dynamic environment.

It would now be imperative to know further about the concepts of exploitation and exploration:

1. Exploitation attempts to represent aspects like efficiency, productivity, control, and initiating action based on experience. It is also said to be associated with "mechanistic structures" and systems, control and bureaucracy, as well as stable markets and technologies (He \& Wong, 2004; Ancona et al., 2001; Lewin et al., 1999). Exploitative activities tend to provide a sort of incremental improvement within the normal routines that are already established in an organization. This activity is capable of contributing to the current operational efficiencies of the organisation and ensuring that there is a stable short-term profitability (March, 1991).

2. Exploration is associated with "organic structures" and loose systems, improvisation, greater autonomy and chaos, as well as a sort of emerging markets and technologies (He \& Wong, 2004). Exploration is associated with concepts that are likely to contribute towards adaptation, like search and discovery, innovation, and looking ahead for the unknown (O'Reilly \& Tushman, 2007). Explorative activities lead to new approaches and ideas and tend to deviate from the current level of operations. They are capable of providing the organization with future opportunities that could be beneficial for long-term profitability (March, 1991).

Based on the above discussions OA can be considered to be the ability of a firm to jointly pursue radical as well as incremental innovation. This is echoed by a number of social scientist and management experts (O'Reilly \& Tushman, 2007; Li, Lin \& Chu, 2008; Raischet al., 2009; Simsek, Heavey, Veiga \& Souder, 2009; Sinha, 2013; Prange \& Schlegelmilch, 2010; Mattes \& Ohr, 2013; Tushman \& O’Reilly, 1996; Vera \& Crossan, 2004).

\section{Theoretical underpinnings}

Models of ambidexterity. Organizational ambidexterity is often discussed through two models: structural ambidexterity and contextual ambidexterity.

1. Structural ambidexterity (SA): Structural ambidexterity facilitates different organizational units to perform separate activities simultaneously (Gibson and Birkinshaw, 2004). Further, the organizational design should be such that it separates the exploitative and explorative activities into distinct organizational units. Each such unit should have distinct and unique competencies, systems, processes, and cultures. All these should strive in the establishment of a planned integration of both exploration and exploitation (Schulze, Heinemann \& Abedin, 2008; Benner \& Tushman, 2003). Structural ambidexterity should aim at implementing and focusing on alignment as well as adaptation (Birkinshaw \& Gibson, 2004). Here the key decisions are taken by the top management. 
2. Contextual ambidexterity (CA): CA enables organizations in balancing both exploitative and explorative tasks without separation (Schulze, Heinemann \& Abedin, 2008). It encourages organizational members to assign their available time between the various compelling and conflicting demands based on the different systems and processes (Gibson and Birkinshaw, 2004). CA is also considered as interplay of system capacities that help in aligning and adapting the entire business. For the successful accomplishment of tasks, it emphasises mostly on the behavioral capacity of the organization (Gibson $\&$ Birkinshaw, 2004). According to them ambidextrous organizations are capable of building high-performing organizational context. This provides employees with the flexibility to use their own judgments for alignment and adaptability, as well as exploitation and exploration. Thus CA facilitates organisations to overcome the so called "structural inertia" (Levinthal \& March, 1993), and strive for innovative and superior performance (Tushman \& O'Reilly, 1996; Štefko and Steffek, 2017). In CA key decisions are made by the salespeople, the supervisors or the frontline employees.

However, there is another school of thought that states that there are three ways of OA - structural, context, and leadership. While the structural and contextual mechanisms are as per the above discussion, leadership stresses on the definite and compelling responsibility of top management to have a fine balance between exploration and exploitation (Lubatkin, Simsek, Ling \& Veiga, 2006). Development of OA is to be organization wide and requires, without exception, the whole hearted engagement of multi-levels of management. This could include the individual, various teams, as well as intra/inter-organizational levels (Yan, et al, 2016).

Now the pertinent question is which of the two is more sustainable. The answer to this question rests in the basic premise of CA. There is no second doubt that CA can be achieved through enabling and encouraging the employees to divide their attention between exploitative and explorative tasks. This challenges the basic concept of SA. Thus, according to Gibson \& Birkinshaw (2004) "CA is potentially a more sustainable model". This is because CA enables adaptation across the business unit, and not just the subunits.

From the above discussions it is clear that it is CA that is desirable for any business unit to make it ambidextrous. There are a set of factors or antecedents that influence in developing ambidexterity in any business, and maintaining it at suitable levels. The antecedents of ambidexterity are now discussed. According to Gibson and Birkinshaw (2004) there are four precursors or antecedents of CA, as presented in Table 1.

Table 1. Antecedents of Contextual Ambidexterity

\begin{tabular}{|c|c|c|}
\hline No. & Antecedents & Details \\
\hline 1 & Discipline & $\begin{array}{l}\text { Discipline is the standards and culture within the organization that encourage individuals to exceed business } \\
\text { expectations (Gibson \& Birkinshaw, 2004). A few aspects that contributes towards or facilitate discipline could } \\
\text { include: } \\
\text { a) clear standards that should spell out the required performance as well as the conduct, } \\
\text { b) unambiguous systems that facilitate timely and candid feedback, and } \\
\text { c) consistency in the application of standards, performance measures or sanctions }\end{array}$ \\
\hline 2 & Stretch & $\begin{array}{l}\text { Stretch involves helping individuals to voluntarily strive for ambitious objectives (Ghoshal \& Bartlett, 1994). } \\
\text { This could include the developing a "shared ambition", "collective identity", as well as "personal meaning"; } \\
\text { which could help individuals to contribute in achieving the overall objectives of the organization (Gibson } \\
\text { \& Birkinshaw, 2004). In such a situation employees have a pristine understanding of how his contribution } \\
\text { helps in the overall performance and objectives of the company, whereby he is able to create a sense of shared } \\
\text { responsibility and personal involvement. }\end{array}$ \\
\hline 3 & Support & $\begin{array}{l}\text { The organizational attribute that facilitates individuals to readily access those resources controlled by others is } \\
\text { known as support. It also provides the individuals with freedom to utilize these resources for the achievement } \\
\text { of achievement of organizational goals (Gibson \& Birkinshaw, 2004. This would require the active support of } \\
\text { the top management, supportive leaders and a conducive environment (Tushman \& O'Reilly, 1997). Support } \\
\text { could also include harnessing of the organisational IT systems to increase sharing of knowledge and best } \\
\text { practices. }\end{array}$ \\
\hline 4 & Trust & $\begin{array}{l}\text { Trust involves the perception of equity and fairness by the employees of all levels about the top management } \\
\text { decisions (Ghoshal \& Bartlett, 1994). It could also include the involvement of individuals in those decisions } \\
\text { that could affect them. According to Adler, Goldoftas \& Levine, (1999), if a high-trust organization is to be } \\
\text { developed, there should be the three essential elements of consistency, competency, and congruence. }\end{array}$ \\
\hline
\end{tabular}


The above behaviours coupled with a supportive organisation inspire the individuals to engage in both exploitation and exploration, leading to CA and enhanced performance. All these are achieved through innovations. CA can also be facilitated though the dissemination of information about new practices and processes throughout the length and breadth of the organization, and ensuring that such practices are learned and positively implemented (Napier, Mathiassen \& Robey, 2011). According to Rothaermel \& Alexandre (2009), CA would help in reducing risks, increasing the competitive advantage; and the resultant higher return-on-investments.

Need for Ambidexterity. Ambidexterity is imperative and indispensible for both short-term and long-term success of any organisation (Vera \& Crossan, 2004), and is positively related to a host of organizational aspects like growth (He and Wong, 2004), innovation (Jansen et al., 2006), financial performance (Gibson and Birkinshaw, 2004), and so forth. It is also considered as an organizational learning process (Huber, 1991; Yan, et al, 2016). This view was also expressed by Raisch et al, (2009) who argued that ambidexterity "is shaped by the co-evolution of learning mechanisms that change, renew, and exploit the knowledge resources of a company". The most beautiful part of OA is that it is in itself ambidextrous and can be built with focus on different domains like individual product, the whole market, as well as the administration of the organisation (O'Reilly \& Tushman, 2013; Voss \& Voss, 2013). OA has also been found to be associated with firm performance and substantial works have been attempted in this area (Auh \& Menguc, 2005; Cao et al., 2009; Ebben \& Johnson, 2005; Fu, Ma, Bosak \& Flood, 2015; He \& Wong, 2004; Jansen et al., 2006, Patel, Messersmith \& Lepak, (2013). Fu et al (2015) succeeded in empirically proving that "the more ambidextrous an organization is, the higher the level of performance". All these bring forth, without ambivalence, the need for ambidexterity in organisations.

Corporate sustainability. Sustainability is a topic that has been extensively researched (Korauš, Kaščáková, Parová\&Veselovská, 2017; Sulphey, 2017; Sulphey \& Alkahtani, 2017). Specific areas researched include innovation (Ahmed, McGough \& Mateo-Garcia, 2017; Barberis, Roncallo \& Traverso, 2017; García-Fuentes\& De Torre 2017; Laužikas, Miliūtė, Tranavičius \& Kičiatovas, 2016; Mouraud 2017; Rosha \& Lace, 2015; Tvaronavičiené, 2016), employer branding (Bendaravičienè, 2017); business models (Prause, 2015); social entrepreneurship (Sulphey \& Alkahtani, 2017); environmental safety (Sulphey, 2017); behavioural pattern (Rosha \& Lace, 2015); and so forth.

Though "Sustainability" became a buzzword after the Rio Conference, the focus towards "Corporate sustainability" (CS) got initiated only in the Mid 90s (Dyllick \& Hockerts, 2002). Since then CS has been gaining increased focus and attention in management literature (Jurigová, Tučková \& Kuncová, 2016; Priess, Rajnoha, Losert, Vogel \& Teufel, 2017; Schaltegger \& Burritt, 2005; Sulphey \& Alkahtani, 2017; Moneva, Archel \& Correa, 2006; Moneva \& Ortas, 2010).CS involves a host of actions by which organizations strive for financial success, even while accepting responsibility for their actions and its impacts on a diverse group of stakeholders. According to the International Corporate Sustainability Barometer - ICSB (2013), CS “implies that economic, environmental and social aspects are simultaneously integrated into a company's conventional management activities."It is also considered as the discipline "by which companies align decision-making about the allocation of capital, product development, brand and sourcing with the principles of sustainable development, in a resource-constrained world" (Global Association of Corporate Sustainability Officers, 2011).

CS emerged due to the understanding among corporate that they need to adapt themselves with urgency to meet the dynamic and hedonistic global environmental. In business organizations sustainability includes both operational and strategic dimensions. Further, sustainability has the unique advantage of providing the managements with vital information that could help in identifying and developing innovative processes and products that could add to shareholder value. CS should also be such that shareholder value is impacted as a result of risks that are associated with social and environmental issues, as much as the strategic and operational issues. The ICSB (2013) is of the opinion that CS, in addition to helping the organisation to attain sustainable development, contributes in directing the society and economy towards this.

CS can occur as a result of both Push and Pull factors (Babiak \& Trendafilova 2011; Ditlev-Simonsen \& Midttun 2011; Moneva \& Ortas 2010). While Push factors include striving for organisational legitimacy through 
sustainability-related Governmental rules and regulations as well as pressure from various stakeholders; Pull factors include the incentives offered by the customers and investors to the organisation in the form of market success. The benefits of CS are manifold. In addition to delivering internal motives of sustainability like efficiency improvement and enhanced employee motivation, CS also has certain external motives like achieving legitimacy, as well as market success (Bansal \& Roth 2000; Epstein 2008).

For developing CS, the company needs to link environmental and social components to strategic, operational and economic success. It should also integrate its deep engagement towards sustainability into its core business. This integration would require the active support and involvement of the whole organisation (ICSB, 2013). Without this support and involvement, CS will remain a mirage. A model that spells out the components of CS is presented in Table 2.

Table 2. Components of Corporate Sustainability

\begin{tabular}{|c|c|c|}
\hline No & Components & Description \\
\hline 1 & Economic & $\begin{array}{l}\text { The economic component involves the ability of a corporate to survive and thrive through operations that } \\
\text { fully internalize all relevant costs. It should also provide for appropriate responses towards predictable } \\
\text { and unpredictable future events. The component should include prudent financial planning and the use } \\
\text { of appropriate risk management systems so that the continued ability to operate profitably is assured. A } \\
\text { sustainable corporation is also transparent in its operations with respect to all its stakeholders. }\end{array}$ \\
\hline 2 & Environmental & $\begin{array}{l}\text { This is the ability of the corporate to produce goods and services with zero ecological impact. Towards } \\
\text { this the corporate should use processes and systems that are non-polluting, conserves energy and natural } \\
\text { resources, ensure safety and health of workers and other stakeholders. It should also have a firm commitment } \\
\text { towards its customers and the communities. Other commitments to the environment include implementing } \\
\text { pollution prevention and control practices; use of recycled, non-polluting and non-toxic input materials } \\
\text { wherever possible; and using safe and recyclable products for packing. }\end{array}$ \\
\hline 3 & Social & $\begin{array}{l}\text { The Corporation should assure opportunities for all stake holders to fully participate in all activities, benefits } \\
\text { and the process of decision-making. It should assign adequate value to capital (both human and natural) and } \\
\text { involve in all round productivity improvements. It should also strive to enhance social security and contact } \\
\text { rather than consumption. In terms of employment, sustainable corporates should allow more people to enjoy } \\
\text { satisfying employment and financial wellbeing. }\end{array}$ \\
\hline 4 & Operational & $\begin{array}{l}\text { In terms of operational component, the corporate should incorporate all round efficiencies and effectiveness in } \\
\text { its objectives, structure and activities. Trouble free systems that facilitate monitoring and measuring activities } \\
\text { and outputs that are capable of providing necessary feedback for continuous improvement should be in place. } \\
\text { The communication system of the corporate should be such that it assures hassle free internal knowledge of } \\
\text { its performance, and maintains harmony with stakeholders, customers and communities. }\end{array}$ \\
\hline 5 & Strategic & $\begin{array}{l}\text { The corporate has to adopt only such business strategies and activities that are capable of meeting its present } \\
\text { needs; while protecting, sustaining and enhancing the human and environmental factors that will assure } \\
\text { continued future performance. For this it should have a management that is capable of understanding and } \\
\text { embracing corporate values, and providing the required leadership and vision that can inspire performance } \\
\text { and investor confidence. It should only select and focus on such products that meet the current and future } \\
\text { needs of a broad array of customers and stakeholders. The strategic component should also consider aspects } \\
\text { like where to manufacture, how the operations are to be conducted, the market where the products is to be } \\
\text { sold, the suppliers that can facilitate current and future needs, as well as the vendors who would be capable of } \\
\text { providing cost-effective equipments and services. }\end{array}$ \\
\hline
\end{tabular}

CS cannot be achieved by a single body or stakeholder in isolation. SD is a pervasive system-wide philosophy to which all stakeholders and participants must subscribe. Only through this could it be possible to meet the current needs without compromising the ability of future generations to meet their own.

Need for CS. A couple of decades back the concept of sustainability was considered to be an expensive inconvenience or a luxury by many corporate. Now sustainability is an absolute necessity for existence and survival. Sustainability is an imperative and now forms the core of the corporate strategy. Any business to be successful and to attain sustainable growth must have the quality of being inclusive, and make real contributions to the all round development of the respective communities within which they operate.

CS is a two way process, and it also has the capability of creating a positive halo about the company amongst the members. It also develops the right attitude among the members so that the demands and expectations of custom- 
ers and other stakeholders are met in the required manner. Further, CS should not be relegated to the periphery, but should be brought to the forefront and considered as an indispensible and integral part of a company's core business (Porter \& Kramer 2006; Schaltegger, Lüdeke-Freund \& Hansen, 2012; Fedorko, et al. 2017). Sustainability should be part of corporate DNA, as it has the capability of offering a competitive advantage and acts as a differentiator. It covers a broad spectrum of aspects like innovation, business ethics, corporate social performance, global corporate citizenship, and stakeholder management. These aspects would help in creating a culture of sustainability that begins with staff, transcending all the levels of the organization. Each and every member of the organization should understand the meaning of sustainability and its importance; as it influences aspects like reputation, brand, product innovation and the different dimensions of relationships with the stakeholders.

All these presents the strong case that real benefits will accrue to the organization only though a rigorous form of performance thorough innovation. This would require all-round proactive changes in the processes coupled with a management philosophy that is long-term in nature. Hence there is a need to redesign the production and delivery process through developing, acquiring and implementing modern technologies, so that the required economic advantages against competitors are delivered. This can be accomplished only through a band of dedicated and innovative minds. This presents the definite need for OA in general and CA in particular. Another aspect that presents a strong case for CA can be derived from the so called "cornerstones" of CS.

Cornerstones of CS. If CS is to be a reality, there is a need to change the corporate mindset. CS strategies need to initiate innovation across the organization, and it should be viewed as a journey, rather than an end in itself. A brief journey down the history will show that successful corporate' are those who have radically altered their business models through innovative approaches. For this they require a leadership that challenges status quo, initiates change, and guides by example. It should also be seen that the intended changes percolate down to all levels of organization, including other stakeholders. Thus to achieve CS the following cornerstones, as presented in Table 3 are indispensible.

Table 3. Cornerstones of CS

\begin{tabular}{|c|c|c|}
\hline No & Cornerstones & Description \\
\hline & Innovation & $\begin{array}{l}\text { Innovation is discovering new ways of value creation. Employees are often classified as innovators and } \\
\text { implementers. Innovators are those who do things differently. They seek new ways of doing, and break the } \\
\text { rules or past practices to solve problems. Implementers prefer to work within the existing rules, 'do the right } \\
\text { things', represent status quo, and serve important roles in the company. } \\
\text { In the present fiercely competitive world, for any organization to survive, grow and succeed; it should depend } \\
\text { on developing innovative technologies, products and services. In any successful organization, innovation is a } \\
\text { sustainable and on-going process. Further, an innovative organization must be fluid, biological and organic in } \\
\text { nature. This is absolute necessity to foster creativity, and is vital for the success for any organization. }\end{array}$ \\
\hline & Engagement & $\begin{array}{l}\text { Today all business operations face a wider range of stakeholder expectations and higher levels of public } \\
\text { scrutiny. The corporate strategies are put to strict scrutiny regarding definitions and executions by the } \\
\text { governments, capital markets, financial institutions, consumers, and employees. The corporates require a } \\
\text { holistic approach to engage the various stakeholders in sustainability related governance issues. Engaging } \\
\text { various stakeholders on sustainability issues should be considered a strategic necessity by the companies. } \\
\text { The stakeholders can be engaged at the corporate, project/site or at specific issues levels. For each level of } \\
\text { engagement, with active support and participation of the senior management, the companies need to identify } \\
\text { specific sustainability risks and deal with it appropriately. }\end{array}$ \\
\hline & Transparency & $\begin{array}{l}\text { In the present corporate world, the objective of business community is not merely limited to making profits. } \\
\text { Investors and stakeholders are deeply interested in knowing how the profits are made. Increased consciousness } \\
\text { among the public and stringent government regulations are leading to all round demands for transparency } \\
\text { in operations. These requirements of the internal and external stakeholders have compelled the corporates } \\
\text { to bring in a paradigm shift towards being transparent in all their activities. To achieve this transparency } \\
\text { organizations involve in measuring and reporting sustainability performances. This transparency could } \\
\text { enhance operational efficiency, improve brand positioning, and above all develop market leadership }\end{array}$ \\
\hline & Accountability & $\begin{array}{l}\text { If CS is to be successful, it requires the active participation of the senior management. They have the } \\
\text { responsibility to see that all the relevant decisions are taken in a timely and orderly manner. Further, the } \\
\text { evaluation of all sustainability issues should be done at the Board level. Further, successful governance } \\
\text { requires the translation of sustainability performance goals into executive targets is an accepted norm in the } \\
\text { present scenario. Attempts towards this end should have the quality of being wholehearted and orderly. }\end{array}$ \\
\hline
\end{tabular}


The organization should have the culture wherein people are free to discuss contrarian views, clash of ideas are encouraged, and a there is a positive mindset to accept dissent. It should also be borne in mind that dissent is capable of acting as a value enhancer. Diversity and differences can facilitate in the generation of ideas and stimulation of innovation. Synergy between members and team work occurs only if they are open towards each other. This could be facilitated by disclosure, which is a prerequisite for mutual trust and a key to successful team work. Certain other integral factors include transparency in operations, as well as responsibility and accountability towards all stakeholders. Reporting is expected to cover economic, social and environmental dimensions.

From the foregone discussion, it can very well be inferred that sustainability is a journey, and not a destination. It demands organisations to have a cycle of continual improvement, and be clear about the journey. There should be clarity of mind regarding the strategies to be adopted - be it safeguarding the market position, responding to competition, creating value as the market matures, or deciding on the changes required in supply chain. There should also be clarity about the cost of not developing a sustainability strategy. To make all these aspects a reality there is a definite and clear need to have innovation in all spheres of the organisation. Herein arises the role of ambidexterity, or more precisely CA. There is a definite paucity of literature connecting the concepts of OA and CS. Raisch et al, (2009) touched upon it when he proposed OA as a solution that is capable of delivering sustainable competitive advantage. The present work intends to fill this major gap in management literature.

A word of caution. Before going into the business case for CA, there is a definite need to have a word of caution about CS. Despite all the favourable aspects about CS, it should be borne in mind that no organization can afford to move ahead under the premise that success will invariably follow sustainability. There is always a challenge on the part of the corporates to be cautious and watch for signs to the contrary, and utilize those signs as a catalyst for the required positive change. Thus corporates must be capable of taking themselves on the illuminating journey of sustainability, instinctively and intuitively grasping mismatches that may crop up in the process. This will help in connecting the entire band of stakeholders with their strategy.

Business Case for CA. It is common knowledge that sustainability is a prelude to innovation and aids business competitiveness. If the innovations are to be sustainable, there is a definite need for the following ingredients, which are indispensible:

1. Value creation: Innovative ideas by itself are of no use unless they are capable of adding value to the respective organisations. Innovation should be such that it creates value, and simultaneously stimulates survival and growth of the organization. A corporate to be successful should cultivate appropriate creative and innovative ideas that could have the potential of adding value - both long term and short term.

2. Dynamism: Innovation to be successful should be a dynamic process that is capable of sustaining itself. In the process of innovation all the stakeholders must be included, taking concerted efforts to see that none are left out. Thus should be borne out of the realization that creativity and innovation can come from anybody.

3. 'Out of the box thinking': Innovation should help the human resources to broaden their perspective and think 'out of the box' and be creative in all aspects. This would enable them in overcoming their ego and the inculcation of a feeling that there are definetly other and better ways of conducting business. In a creative organization, people are being led rather than being managed.

For these to happen there should be both exploitation and exploration. While the former provides incremental improvement, the later deviates from current level of operations and result in new operations. However, a compelling problem that is often faced by organisations is the trade-off between exploitation and exploration. This occurs due to scant top managerial interest and attention, coupled with scarcity ofvarious resources. It is strongly argued that concentration on either of the two could wreck havoc resulting in disaster to the organization. This "singular focus" is also fraught with a form of overt aggressiveness (Auh \& Menguc, 2005; March, 1991), which again could invariably be detrimental. Another problem that is observed is that at times organizations over-emphasize on exploitation without due importance to exploration. According to March (1991) this 
imbalance could be self-destructive to the organisation. This self-destruction could occur because there is the possibility of organizations getting "trapped" in obsolescence, losing the golden opportunity to lead in future markets. Conversely, if an organization indulges in endless exploration, it could have to face considerable uncertainties, and ultimately exhaust the available scarce resources (Auh and Menguc, 2005). Thus, OA can be developed only through gaining, developing and sustaining the competitive advantage.

Business case for CS. Substantial literature exists with respect to societal and market-relevant drivers that are linked to the business cases for sustainability (Steger 2004; Schaltegger \& Lüdeke-Freund 2012; Schaltegger et al. 2012). They include internal drivers like efficiency and employee motivation, and external drivers like reputation and revenue. For a business that focuses on CS, all the corporate functions, both internal and external will be challenged to contribute towards sustainability. Further, when companies consider sustainability as an integral and indispensable part of their strategic and operational planning, there are ample scope for vast business opportunities and changes in their processes, products and services (Schaltegger \& Wagner, 2011).

\section{Conclusion}

From the foregone conclusion, it can very well be inferred that there are substantial amount of overlapping between the concepts of CA and CS; or rather each one seem to complement and aid the other. Innovation, engagement, transparency, etc. form the cornerstone of both the concepts. If both of them are suitably and harmoniously blended, it will definitely go a long way in making 'sustainability sustainable' and for delivering manifold benefits to all stakeholders. This could facilitate driving a bottom line strategy that can reduce costs; a top line strategy that broadens consumer base; as well as a talent strategy that attracts, retains, develops and galvanizes employees, customers and the society. This is also capable of providing insights about cost reduction and optimization. Further, measuring the various sustainability factors and lacing them with CA for the purpose of decision-making would ensure that sustainability is embedded in the day-to-day life of the organization. This will help corporate become ambidextrous and taking themselves on the illuminating journey of sustainability, instinctively grasping mismatches that may crop up in the process. This will also help in connecting and taking along the entire band of stakeholders with their strategy.

There is no doubt that a contextually ambidextrous organisation will be sustainable; and sustainability will help in making an organisation in attaining contextual ambidexterity. Both CA and CS are bi-directional and mutually exclusive in nature. Further, the complementarities of OA and CS are definite to present a promising direction for future research works. The present study has also helped in extending the knowledge about the mediating role that ambidexterity plays in the attainment of sustainability. There is a definite need for further exploration, both theoretically and empirically in identifying and linking the two concepts so that organisations can be made to face the ever increasing challenges in the present day competitive and hedonistic markets. At present there exist only few empirical works about OA and its relationship with other concepts. The present work, despite its inherent limitations of being conceptual in nature is expected to be of guidance for further exploration in this evolving and promising area of management. It is expected that more scholarly examination will be undertaken in this highly potential area. 


\section{References}

Abernathy, W. J. (1978). The productivity dilemma, Baltimore: Johns Hopkins University Press.

Adler, P. S.; Goldoftas, B.; Levine, D. I. (1999). Flexibility versus efficiency? A case study of model changeovers in the Toyota production system. Organization Science, 10, 43-68. https://doi.org/10.1287/orsc.10.1.43

Ahmed, A.; McGough, D.; Mateo-Garcia, M. (2017). Testing innovative technologies for retrofitting: Coventry University as a living lab, Entrepreneurship and Sustainability Issues, 4(3), 257-270. http://dx.doi.org/10.9770/jesi.2017.4.3S(2)

Andriopoulos, C.; Lewis, M. W. (2009). Exploitation-exploration tensions and organizational ambidexterity: managing paradoxes of innovation. Organization Sience, 20(4), 696-717.https://doi.org/10.1287/orsc.1080.0406

Armour, A. F. (2015). Achieving Contextual Ambidexterity through the Implementation of High Performance Work Systems (HPWS). Dissertation, Georgia State University, 2015. Available at http://scholarworks.gsu.edu/bus_admin_diss/55

Auh, S.; Menguc, B. (2005). Balancing exploration and exploitation: The moderating role of competitive intensity. Journal of Business Research, 58(12), 1652-1661. http://doi.org/10.1016/j.jbusres.2004.11.007

Babiak, K.; Trendafilova, S. (2011). CSR and environmental responsibility: motives and pressures to adopt green management practices, Corporate Social Responsibility and Environmental Management, 18(1), 11-24. http://hdl.handle.net/2027.42/79421

Bansal, P.; Roth, K. (2000). Why Companies Go Green. A Model of Ecological Responsiveness. The Academy of Management Journal, 43(4), 717-736. https://www.jstor.org/stable/1556363?seq=1\#page_scan_tab_contents

Barberis, S.; Roncallo, F.; Traverso, A. (2017). Towards innovative district energy management: a case study with stochastic renewable generators, Entrepreneurship and Sustainability Issues, 4(3), 294-309. http://dx.doi.org/10.9770/jesi.2017.4.3S(5)

Bendaravičienè, R. (2017). Towards sustainable organization: integrative conceptual model for employer branding, Journal of Security and Sustainability Issues 6(4), 649-662. http://doi.org/10.9770/jssi.2017.6.4(10)

Benner, M. J.; Tushman, M. L. (2003). Exploitation, exploration, and process management: The productivity dilemma revisited. Academy of Management Review, 28, 238-256. http://www.business.uzh.ch/professorships/som/stu/Teaching/FS10/MA/som/Benner_Tushman_2003_expl_lead.pdf

Birkinshaw, J.; Gibson, C. (2004). Building ambidexterity into an organization. MIT Sloan Management Review, 45, 47-55.

Cao, Q.; Gedajlovic, E.; Zhang, H. (2009). Unpacking organizational ambidexterity: dimensions, contingencies, and synergistic effects. Organization Science, 20(4), 781-796. http://www.sfu.ca/ erg/research/ambidexterity.pdf

Chang, Y. Y.; Hughes, M.; Hotho, S. (2011). Internal and external antecedents of SMEs' innovation ambidexterity outcomes. Management Decision, 49(10), 1658-1676. https://doi.org/10.1108/00251741111183816

Ditlev-Simonsen, C.D.; Midttun, A. (2011). What Motivates Managers to Pursue Corporate Responsibility? A Survey among Key Stakeholders. Corporate Social Responsibility and Environmental Management, 18(1), 25-38. http://hdl.handle.net/11250/293433

Duncan, R. B. (1976). The ambidextrous organization: designing dual structures for innovation. in Kilmarm, R.H., Pondy, L.R. and Slevin, D. (Eds), The Management of Organization Design: Strategies and Implementation, North Holland, New York, NY.

Dyllick, T \& Hockerts, K. (2002). Beyond the business case for corporate sustainability, Business strategy and the environment, 11(2), 130-141. http://dx.doi.org/10.1002/bse.323

Ebben, J. J.; Johnson, A. C. (2005). Efficiency, flexibility, or both? Evidence linking strategy to performance in small firms. Strategic Management Journal, 26(3), 1249-1259.

Epstein, M.J. (2008). Making Sustainability Work. Best Practices in Managing and Measuring Corporate Social, Environmental, and Economic Impacts. Sheffield: Greenleaf https://www.bkconnection.com/static/Making_Sustainability_Work_2nd_EXCERPT.pdf

Fedorko, R.; Bačík, R.; Kerul'ová, V. (2017). The analysis on the importance of the reputation management in relation to e-commerce subjects. Polish Journal of Management Studies, 15(1), 48-56. http://doi.org/10.17512/pjms.2017.15.1.05

Fu, N.; Ma, Q.; Bosak, J.; Flood, P. (2015). Exploring the relationships between HPWS, organizational ambidexterity and firm performance in Chinese professional service firms. Journal of Chinese Human Resource Management, 6(1), 52-70. https://doi.org/10.1108/ JCHRM-09-2014-0029 
García-Fuentes, M. A. \& de Torre, C. (2017). Towards smarter and more sustainable regenerative cities: the REMOURBAN model, Entrepreneurship and Sustainability Issues, 4(3), 328-338. http://dx.doi.org/10.9770/jesi.2017.4.3S(8)

Gibson, C. B.; Birkinshaw, J. (2004). The antecedents, consequences, and mediating role of organizational ambidexterity. The Academy Of Management Journal, 2, 209 -225. http://faculty.london.edu/jbirkinshaw/assets/documents/Role_of_organisational_ambidexterity. Academy_of_management.2004.pdf

Ghoshal, S.; Bartlett, C.A. (1997). The individualized corporation: A fundamentally new approach to management. Harper Business.

Global Association of Corporate Sustainability Officers (GACSO) (2011). Defining and developing the corporate sustainability professional - the practitioners'view. Version 1. Available at http://www.gacso.org/Resources/Documents/defining\%20the\%20corporate\%20 sustainability\%20professional.pdf

He, Z. L.; Wong, P. K. (2004). Exploration vs exploitation: an empirical test of the ambidexterity hypothesis. Organization Science, 15(4), 481-494. https://doi.org/10.1287/orsc.1040.0078

Huber, G. P. (1991). Organizational learning: the contributing processes and the literatures. Organization Science, 2(1), 88-115. https://doi.org/10.1287/orsc.2.1.88

International Corporate Sustainability Barometer (2013). Center for Sustainability Management e.V., Leuphana Lüneburg, Germany: University Lüneburg.

Jansen, J. J. P.; Van den Bosch, F. A. J.; Volberda, H. W. (2005). Exploratory innovation, exploitative innovation, and ambidexterity: the impact of environmental and organizational antecedents. Schmalenbach Business Review, 57, 351-363.

Jansen, J. J. P.; Van den Bosch, F. A. J.; Volberda, H. W. (2006). Exploratory innovation, exploitative innovation, and performance: effects of organizational antecedents and environmental moderators. Management Science, 52(11), 1661-1674.

Jansen, J. J. P.; George, G.; Van den Bosch, F. A. J.; Volberda, H.W. (2008). Senior team attributes and organizational ambidexterity: the moderating role of transformational leadership. Journal of Management Studies, 45(5), 982-1007.

Jurigová, Z.; Tučková, Z.; Kuncová, M. (2016). Economic sustainability as a future phenomenon: moving towards a sustainable hotel industry, Journal of Security and Sustainability Issues, 6(1), 103-112. http://dx.doi.org/10.9770/jssi.2016.6.1(7)

Jurksiene, L \& Pundziene, A. (2016). The relationship between dynamic capabilities and firm competitive advantage: The mediating role of organizational ambidexterity, European Business Review, 28(4), 431-448, https://doi.org/10.1108/EBR-09-2015-0088

Kathuria, A.; Konsynski, B. R. (2012). Juggling paradoxical strategies: the emergent role of IT capabilities. Thirty third International Conference on Information Systems, Orlando, FL, December 16-19.

Korauš, A.; Kašćáková, Z.; Parová, V.; Veselovská, S. (2017). Sustainable economic development through human resource management: social intelligence of managers and performance. Journal of Security and Sustainability Issues, 6(3): 457-477. http://dx.doi. org/10.9770/jssi.2017.6.3(11)

Laužikas, M.; Miliūtè, A.; Tranavičius, L.; Kičiatovas, E. (2016). Service Innovation Commercialization Factors in the Fast Food Industry, Entrepreneurship and Sustainability Issues, 4(2), 108-128. http://dx.doi.org/10.9770/jesi.2016.4.2(1)

Lavie, D.; Stettner, U. \& Tushman; M. L. (2010). Exploration and exploitation within and across organizations. The Academy of Management Annals, 4, 109-155.

Levinthal, D. A.; \& March, J. G. (1993). The myopia of learning. Strategic Management Journal, 14, 95-112.

Li, C.R.; Lin, C.J.; Chu, C.P. (2008). The nature of market orientation and the ambidexterity of innovations. Management Decision, 46(7), 1002-1026.

Lubatkin, M. H.; Simsek, Z.; Ling, Y. \& Veiga, J. F. (2006). Ambidexterity and performance in small-to medium-sized firms: the pivotal role of top management team behavioral integration. Journal of Management, 32(5) 646-672.

March, J. G. (1991). Exploration and exploitation in organizational learning. Organization Science, 1, 71-84.

Mattes, F. and Ohr, R. C. (2013). Balancing innovation via organizational ambidexterity - Part 3. Innovation Management Online Concepts, available at: www.innovationmanagement.se/2014/03/12/balancing-innovation-via-organizational-ambidexterity-part-3/.

Mouraud, A. (2017). Innovative time series forecasting: auto regressive moving average vs deep networks, Entrepreneurship and Sustainability Issues, 4(3), 282-293. http://dx.doi.org/10.9770/jesi.2017.4.3S(4) 
Moneva, J. M.; Archel, P.; Correa, C. (2006). GRI and the camouflaging of corporate unsustainability. Accounting Forum, 30(2), 121-137.

Moneva, J. M.; Ortas, E. (2010). Corporate environmental and financial performance: a multivariate approach. Industrial Management \& Data Systems, 110(2), 193-210.

Napier, N. P.; Mathiassen, L.; Robey, D. (2011). Building contextual ambidexterity in a software company to improve firm-level coordination. European Journal of Information Systems, 20, 674-690.

O’Reilly III, C.; Tushman, M. (2007). Ambidexterity as a Dynamic Capability: Resolving the Innovator's Dilemma, Research Paper No. 1963, Research Paper Series, Stanford Graduate School of Business.

Parikh, M. (2016). Move over Mintzberg, let adhocracy give way to ambidexterity, Management Decision, 54(5), 1047-1058, https:// doi.org/10.1108/MD-07-2014-0483

Patel, P.; Messersmith, J.; Lepak, D. (2013). Walking the tightrope: an assessment of the relationship between high-performance work systems and organizational ambidexterity. Academy of Management Journal, 56(5), 1420-1442.

Porter, M. E.; Kramer, M. R. (2006): Strategy \& Society. The Link between Competitive Advantage and Corporate Social Responsibility, Harvard Business Review, 84(12), 78-92.

Prange, C.; Schlegelmilch, B. B. (2010). Heading for the next innovation archetype? Journal of Business Strategy, 31(1), 46-55

Prause, G. (2015). Sustainable business models and structures for industry 4.0, Journal of Security and Sustainability Issues, 5(2), 159-169. https://doi.org/10.9770/jssi.2015.5.2(3)

Priess, P.; Rajnoha, R.; Losert, S.; Vogel, S.; Teufel, H. (2017). Sustainable real estate development and its implications on investment: Statistical relations on the case from Austria, Journal of Security and Sustainability Issues, 6(3), 419-434. http://dx.doi.org/10.9770/ jssi.2017.6.3(8)

Raisch, S.; Birkinshaw, J. (2008). Organizational ambidexterity: antecedents, outcomes and moderators. Journal of Management, 34(3), 375-409.

Raisch, S.; Birkinshaw, J.; Probst, G.; Tushman, M. L. (2009). Organizational ambidexterity: balancing exploitation and exploration for sustained performance. Organization Science, 20(4), 685-695.

Rosha, A.; Lace, N. (2015). Sustainable development and behavioural patterns: to innovations through coaching. Journal of Security and Sustainability Issues, 5(2), 171-180. https://doi.org/10.9770/jssi.2015.5.2(4)

Rothaermel, F. T.; Alexandre, M. T. (2009). Ambidexterity in technology sourcing: The moderating role of absorptive capacity. Organization Science, 20, 759-780.

Rothaermel, F. T.; Deeds, D. L. (2004). Exploration and exploitation alliances in biotechnology: a system of new product development. Strategic Management Journal, 25(3), 201-221.

Schaltegger, S.; Burritt, R. (2005). Corporate Sustainability. In: Folmer, H. \& Tietenberg,T. (Eds.): International Yearbook of Environmental and Resource Economics 2005/2006. A Survey of Current Issues; Cheltenham: Edward Elgar, 185-222.

Schaltegger, S.; Lüdeke-Freund, F. (2012). The “Business Case for Sustainability” Concept: A Short Introduction. Lüneburg: Centre for Sustainability Management

Schaltegger, S.; Lüdeke-Freund, F.; Hansen, E.G. (2012). Business Cases for Sustainability: The Role of Business Model Innovation for Corporate Sustainability, International Journal of Innovation and Sustainable Development, 6(2), 95-119.

Schaltegger, S.; Wagner, M. (2011). Sustainable Entrepreneurship and Sustainability Innovation. Categories and Interactions, Business Strategy and the Environment, 20(4), 222-237.

Schulze, P.; Heinemann, F.; Abedin, A. (2008). Balancing exploitation and exploration. Academy of Management Annual Meeting Proceedings, 1-6.

Simsek, Z.; Heavey, C.; Veiga, J. F.; Souder, D. (2009). A typology for aligning organizational ambidexterity's conceptualizations, antecedents, and outcomes. Journal of Management Studies, 46(5), 864-894

Sinha, S. (2013). Managing ambidexterity in growth phase of start-up firms. Unpublished PhD thesis, Indian Institute of Management, Ahmedabad. 
Štefko, R.; Steffek, V. (2017). A study of creative industry entrepreneurial incubation Polish Journal of Management Studies, 15 (2), 250-261. http://doi.org/10.17512/pjms.2017.15.2.23

Steger, U. (Ed.) (2004). The Business of Sustainability. Building Industry Cases for Corporate Sustainability, Houndmills: Palgrave Macmillan.

Strielkowski, W.; Shishkin, A.; Galanov, V. (2016). Modern management: Beyond traditional managerial practices Polish Journal of Management Studies, 14 (2), 225-231. http://doi.org/10.17512/pjms.2016.14.2.21

Sulphey, M. M. (2017). Towards sustainable forest management through enhancing safety of nature. Journal of Security and Sustainability Issues, 6(4), 703-710. http://doi.org/10.9770/jssi.2017.6.4(14)

Sulphey, M. M.; Alkahtani, N. S. (2017). Economic security and sustainability through social entrepreneurship: the current Saudi scenario, Journal of Security and Sustainability Issues, 6(3), 479-490. http://dx.doi.org/10.9770/jssi.2017.6.3(12)

Tvaronavičienė, M. (2016). Entrepreneurship and energy consumption patterns: case of households in selected countries. Entrepreneurship and Sustainability Issues 4(1), 74-82. http://dx.doi.org/10.9770/jesi.2016.4.1(7)

Turner, N.; Swart, J.; Maylor, H. (2013). Mechanisms for managing ambidexterity: a review and research agenda. International Journal of Management Reviews, 15(3), 317-332. http://dx.doi.org/10.1111/j.1468-2370.2012.00343.x

Tushman, M. L.; O’Reilly III, C. A. (1996). Ambidextrous organizations: Managing evolutionary and revolutionary change, California Management Review, 38 (4), 8-30. https://doi.org/10.2307/41165852

Vera, D.; Crossan, M. (2004). Strategic leadership and organizational learning. Academy of Management Review, 29(2), 222-240. https://doi.org/10.5465/AMR.2004.12736080

Voss, G. B. \& Voss, Z. G. (2013). Strategic ambidexterity in small and medium-sized enterprises: implementing exploration and exploitation in product and market domains. Organization Science, 24(5), 1459-1477. https://doi.org/10.1287/orsc.1120.0790

Wang, C. L.; Rafiq, M. (2009). Organizational diversity and shared vision. European Journal of Innovation Management, 12(1), 86-101. https://doi.org/10.1108/14601060910928184

Yan, M.; Yu, Y; Dong, X. (2016). Contributive roles of multilevel organizational learning for the evolution of organizational ambidexterity. Information Technology \& People, 29(3), 647-667, https://doi.org/10.1108/ITP-04-2015-0079 